\title{
Patriline composition of worker populations in honeybee (Apis mellifera) colonies headed by queens inseminated with semen from African and European drones
}

\author{
Gloria DEGRANDI-HOFFMAN ${ }^{\mathrm{a} *}$, David R.TARPY ${ }^{\mathrm{b}}$, Stanley S. SCHNEIDER ${ }^{\mathrm{c}}$

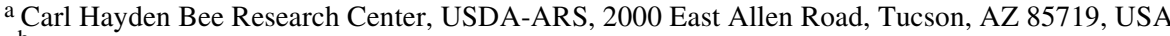 \\ ${ }^{\mathrm{b}}$ Department of Neurobiology and Behavior, Cornell University, Ithaca, New York 14850, USA \\ ${ }^{c}$ Department of Biology University of North Carolina, Charlotte, North Carolina 28223, USA
}

(Received 10 October 2001; revised 29 May 2002; accepted 13 August 2002)

\begin{abstract}
Honeybee queens with either European or African maternity were mated to African and European drones to determine rates of sperm utilization. The first month after the queens were inseminated, they produced equal proportions of workers with African and European paternity. However, for the next 3-4 months, more than $70 \%$ of the workers produced by queens of either matriline had African paternity. Overall, the queens produced a majority of workers with African paternity during the six-month study period. The possible impact that a higher rate of sperm utilization from African drones might have on the Africanization process is discussed.
\end{abstract}

Apis mellifera / Apis mellifera scutellata / sperm utilization / Africanization process

\section{INTRODUCTION}

The spread of Africanized honeybees (AHB) has been well documented in the western hemisphere since their initial introduction in Brazil (e.g., Taylor, 1977; Otis, 1980; Rinderer, 1986). Currently, AHB are established in South and Central America, Mexico, the southwestern US, California and Texas. When AHB immigrate into new areas they almost always displace the resident European honeybee (EHB) populations. Nuclear DNA markers that are typically associated with paternally inherited EHB alleles are replaced with those of AHB (Lobo et al., 1989; Hall, 1990; Sheppard et al., 1991; Rinderer et al., 1991; Suazo et al., 1998).
The replacement of European genotypes with those of African genotypes can occur for several reasons. One important factor is the manner that genes are transmitted from one generation to the next within a colony. When a queen mates with both EHB and AHB drones, both types of patrilines are present in a colony. However, when the queen is replaced, only the patriline of the new queen is preserved in the next generation. If queens of African paternity have advantages over those of European paternity to become the replacement queen, it would at least partially explain why AHB genotypes are so highly conserved.

Three lines of evidence suggest that selective advantages exist for queens of African paternity. First, African patriline queens have

\footnotetext{
* Correspondence and reprints

E-mail: gdhoff@aol.com
} 
shorter development times and can emerge before European patriline queens (DeGrandiHoffman et al., 1998). Development rates for queens are important because, in some instances, the first queen to emerge destroys all remaining queen cells and becomes the new queen in the colony (Schneider et al., 2001). Second, African-patriline virgin queens reared in European-matriline colonies exhibit greater piping activity, eliminate more of their rivals, and are more likely to become the new laying queen than their half-sisters with European paternity (Schneider and DeGrandi-Hoffman, 2002). Third, African-patriline queens receive more "vibration signals" from workers, which is associated with longer survival and greater fighting success (Schneider et al., 2001; Schneider and DeGrandi-Hoffman, 2003).

Queens of African descent might also occur with greater frequency if workers with African paternity are more common within a colony. The patriline composition of a colony is a function of the number and proportion of sperm from different drones stored in a queen's spermatheca and used to fertilize eggs. Any mechanism that increases the utilization of sperm from African males, such as intraspermathecal competition (Parker, 1984) or postzygotic selection (Koeniger and Koeniger, 2000), would increase the proportion of African patrilines in a colony and the likelihood that a larva with African paternity becomes a candidate to be the new queen.

Several studies have investigated how European queens utilize sperm. Sperm use was evaluated by counting the number of worker offspring possessing certain phenotypic or molecular markers (e.g., Laidlaw and Page, 1984; Moritz, 1986; Sasaki et al., 1995). Most evidence suggests that sperm are used randomly to fertilize eggs (but see Harbo, 1990). However, since those studies tested only EHB males, it is not known whether sperm from African and European drones fertilize eggs at equal rates. The purpose of this study was to determine the utilization rate of European and African sperm as illustrated by the patriline composition of adult worker populations in colonies. We examined sperm utilization rates in both African and European matriline queens.

\section{MATERIALS AND METHODS}

\subsection{Matriline identification}

Cordovan $(c d)$ queens headed the European matriline colonies used in this study. AHB colonies were captured as swarms in southern Arizona and were characterized using mitochondrial DNA analysis following the procedure of Nielsen et al. (2000). Samples of three workers were taken from 16 AHB swarms, and their DNA was extracted using Chelex ${ }^{\circledR} 100$ resin (Walsh, 1991). EcoRI, HincII, and HinfI restriction enzyme digests were performed on PCR products that used DNA primers specific to honeybee mitochondrial DNA. The digests revealed three Eastern European matrilines, one Western European matriline, and 12 Apis mellifera scutellata matrilines. Of the captured swarms, only the A. m. scutellata were used for further study.

\subsection{Crosses between African and European matrilines and patrilines}

Worker larva from the European and African matrilines were grafted into queen cups and reared into queens using the techniques described in Laidlaw (1977). Three different sources of African matrilines and a single European matriline source were used for the grafts. When the queens were approximately seven days old, each was inseminated with sperm from two drones (unrelated to the queen), one each from an African and a European colony. Semen was collected with an insemination syringe from each male in random succession. Care was taken to collect equal volumes of semen from both males, approximately $1.0 \mu \mathrm{l}$ each. The total volume of semen was injected into a queen while anesthetized with $\mathrm{CO}_{2}$. In all, $11 \mathrm{AHB}$ queens and $10 \mathrm{EHB}$ queens were inseminated. In addition, we inseminated African matriline queens with just African or European drones to create voucher specimens for identifying patrilines.

\subsection{Sampling procedure and patriline identification}

One month after the inseminated queens started to lay eggs, worker offspring were sampled by placing $10.2 \mathrm{~cm} \times 15.2 \mathrm{~cm}$ wire mesh cages over sealed brood in each colony. A total of 10 colonies were sampled, five of each matriline. When the adult workers emerged under the cage, all adult bees on the comb (except those under the cage) were brushed off both sides of the frame. A plastic bag was placed by the cage and the cage was removed. All the workers from under the cage were brushed into the plastic bag, and the sample was 
immediately frozen. On average, we captured 100400 worker bees per sample. We repeated this procedure monthly for six months.

The paternity of workers from colonies headed by either European or African matriline queens were identified by their cuticular color. In colonies headed by the European $(c d)$ queens, workers with European patrilines were yellowish-brown in color and had no black stripes on their abdomen. The workers with African paternity had black stripes across their third or fourth through the seventh abdominal tergites. In the African matriline colonies, workers with African paternity were either completely black, or had solid black stripes on all abdominal tergites. Workers with European paternity had missing or a light brown stripe on the second and sometimes third abdominal tergite. The number of workers in each patriline were counted for each colony for each sampling period.

\subsection{Statistical analysis}

\subsubsection{Overall percentages of European and African patriline workers}

We determined if African and European queens differed in their overall usage of sperm from the two patrilines. We used two approaches to conduct these analyses. First, we examined each of the European and African matriline queens individually. We calculated a mean for the percentage of workers with African paternity that each queen produced over the entire sampling period. We then conducted a Chi-square test on each queen to determine if the mean percentage of workers with African paternity differed from the $50 \%$ expected if sperm from African and European drones were used with equal frequency.

Second, we examined the workers produced by all queens combined within each matriline. We used a Hartley's Test for Homogeneity of Variance to determine if the variance in the percentage of workers with African patrilines produced by the different queens was homogeneously distributed in each matriline (Sokal and Rohlf, 1995). A mean percentage of workers with African paternity was then estimated over all five queens within each matriline. A Chi-square was conducted to determine if average percentages differed from the expected value of $50 \%$.

\subsubsection{Percentages of European and African patriline workers produced over time}

We examined the temporal patterns of sperm usage by calculating for each month of the study the average proportion of workers with African paternity in the five colonies of each matriline. A Chi-Square test was conducted to determine if the average for each month was significantly different from $50 \%$. A Hartley's Test for Homogeneity of Variance was conducted to determine if the variance in the percentage of African-paternity workers produced each month by the five queens of each matriline was homogeneously distributed. If so, the data were pooled within matriline for each monthly sample, and a Chi-Square test was conducted to determine if the average for each month was significantly different from $50 \%$.

\subsubsection{Heterogeneity in the production of European and African patriline workers among queens of each matriline}

We used a replicated test of Goodness-of-Fit to determine if the percentage of African paternity workers produced monthly by each queen deviated from an expected value of 50\% (Sokal and Rohlf, 1995). The Goodness of Fit test was conducted in addition to the Chi-Square analysis to estimate the heterogeneity in the percentage of African paternity workers produced by queens of each matriline over time.

\section{RESULTS}

\subsection{Overall percentages of European and African patriline workers}

We obtained six monthly samples of workers from five colonies of each matriline. We ended the experiment after 6 months because several of the inseminated queens were no longer seen in the colonies and the hives were in the process of rearing new queens.

When examining each queen individually over the six months of the study, European matriline queens produced an average of $37-75 \%$ African patriline workers (Tab. I). Four of the five European matriline queens produced significantly more African patriline workers than expected, while the fifth produced more workers than expected with European paternity. The queens with African matrilines produced 53-72\% African patriline workers and all five produced significantly more workers than expected with African paternity (Tab. I). 
Table I. Average percentages of workers having African paternity produced by five queens of either African or European patrilines during a 6 month sampling interval (1 sample per month). Each queen was instrumentally inseminated with semen from an African and European drone. Chi-square values were estimated based upon expected percentages of workers having African paternity to be $50 \%$.

\begin{tabular}{lccc}
\hline Maternity of queen & Queen & $\begin{array}{c}\text { Average percentage of workers with } \\
\text { African paternity }\end{array}$ & $\begin{array}{c}\text { Chi-square } \\
\text { value }{ }^{1}\end{array}$ \\
\hline European & 1 & $75.1 \pm 4.5$ & 99.2 \\
& 2 & $37.0 \pm 7.7$ & 38.0 \\
& 3 & $59.7 \pm 6.8$ & 47.9 \\
& 4 & $74.3 \pm 4.6$ & 77.3 \\
African & 5 & $57.6 \pm 6.3$ & 25.8 \\
& 1 & $71.6 \pm 10.4$ & 118.2 \\
& 2 & $53.4 \pm 5.8$ & 14.5 \\
& 3 & $72.3 \pm 5.6$ & 56.0 \\
& 4 & $66.5 \pm 8.0$ & 45.6 \\
& 5 & $59.0 \pm 5.0$ & 70.5 \\
\hline
\end{tabular}

Critical value for Chi-square $=11.1$; d.f. $=5$; alpha level $=0.05$.

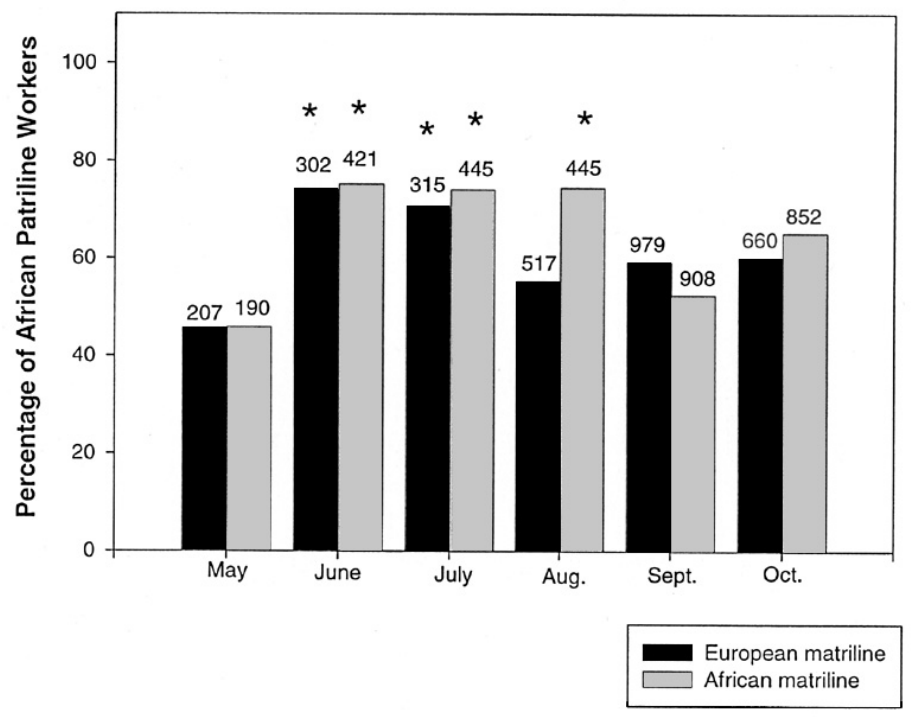

Figure 1. The percentage of workers with African paternity during the 6-month observation period. Numbers above bars represent the number of worker honeybees counted in the sample. The asterisk indicates those percentages that are significantly different from the expected of $50 \%$ as determined by a Chi-square test at the 0.05 alpha level.

The variance in the percentage of workers with African paternity for the European and African maternity queens was homogeneously distributed (European maternity: $\mathrm{F}=2.96$; $\mathrm{df}=5.5 ; P<0.05 ;$ African maternity: $\mathrm{F}=4.3$; df $=5.5 ; P<0.05)$. We therefore combined the data within matriline. The pooled data revealed that the percentages of African patriline workers were significantly different from the expected $50 \%$ for the queens of both matrilines over the 6-month sampling interval. Queens having European maternity produced a combined total of $61 \%$ of their workers with African paternity $\left(\chi^{2}=119.3\right.$; df $=1$; 
Table II. $G$-values from a replicated goodness-of-fit test using data for the percentage of workers with African paternity produced each month by 5 queens with either European or African maternity. $G_{\mathrm{P}}$ is the goodness of fit for the pooled data of workers with African paternity for the 5 queens of each matriline, $G_{\mathrm{H}}$ is the goodness of fit value for heterogeneity among the samples, and $G_{\mathrm{T}}$ is the total $G$-value $\left(G_{\mathrm{P}+} G_{\mathrm{H}}\right)$.

\begin{tabular}{lcccc}
\hline Maternity of queen & Month & $G_{\mathrm{P}}$ & $G$-values & $G_{\mathrm{T}}$ \\
\hline European & May & $0.9^{\mathrm{N}}$ & $56.2^{2}$ & 57.1 \\
& June & $104.1^{1}$ & $17.2^{2}$ & 121.3 \\
& July & $52.8^{1}$ & $21.4^{2}$ & 74.2 \\
& August & $8.3^{1}$ & $88.4^{2}$ & 96.7 \\
& September & 0.1 & $144.0^{2}$ & 144.1 \\
\multirow{3}{*}{ African } & October & $78.3^{1}$ & $34.0^{2}$ & 112.3 \\
& May & 2.1 & 9.0 & 11.1 \\
& June & $80.5^{1}$ & $55.2^{2}$ & 135.7 \\
& July & $93.2^{1}$ & $13.4^{2}$ & 106.6 \\
& August & $167.4^{1}$ & $156.0^{2}$ & 323.4 \\
& September & $6.9^{1}$ & $18.0^{2}$ & 24.9 \\
& October & $57.1^{1}$ & $54.0^{2}$ & 111.1 \\
\hline
\end{tabular}

${ }^{1}$ Chi-Square score for pooled data $\left(G_{\mathrm{P}}\right)$ is significant at the 0.05 alpha level, $1 \mathrm{df}$. All $G_{\mathrm{T}}$ Chi-Square scores were significant at the 0.05 alpha level, $5 \mathrm{df}$.

${ }^{2}$ Chi-Square score for heterogeneity value $\left(G_{\mathrm{H}}\right)$ is significant at the 0.05 alpha level, $4 \mathrm{df}$.

$P<0.001$ ), while African maternity queens produced $65 \%$ African patriline workers $\left(\chi^{2}=226.25 ; \mathrm{df}=1 ; P<0.0001\right)$.

\subsection{Percentages of European and African patriline workers produced over time}

The percentage of workers with African patrilines was not constant during the 6-month observation period (Fig. 1). African drones sired about $50 \%$ of the workers of each matriline during the first month and final two months of the study. However, during the remaining three months of the study, $>70 \%$ of the workers had African paternity. The variance in the percentage of workers with African paternity for queens having European and African maternity was homogeneously distributed for the 6 month sampling period (European maternity: $\mathrm{F}=4.48$; $\mathrm{df}=5.4$; $P<0.05$; African maternity: $\mathrm{F}=5.49$; $\mathrm{df}=5.4$; $P<0.05)$.

\subsection{Heterogeneity in the production of European and African patriline workers among queens of each matriline}

Queens of either matriline fell into two categories. Some produced $<50 \%$ of their worker offspring with African paternity during the first month after insemination and then produced $>50 \%$ for the following months. Others produced predominantly African paternity workers (i.e., > 60\%) for all sampling intervals. Consequently, there was a high degree of heterogeneity among queens of both matrilines in the percentage of African paternity workers they produced throughout the study, with the exception of the African matriline queens in May (Tab. II). Despite the heterogeneity among queens, the G-values for the pooled data $(\mathrm{Gp})$ were significant for both matrilines $\left(\chi^{2}>3.84, P<0.05\right)$, indicating that the proportion of African patrilines was significantly greater than 
expected $(50 \%)$ in all but the first sampling interval (for both matrilines) and for the September sample for the European matrilines only.

\section{DISCUSSION}

This is the first study where sperm utilization has been examined over time in crosses between African and European bees. All but one queen having European maternity produced a majority of workers with African paternity over the six-month sampling period. Assuming equal survivorship of African and European patrilines as immatures, higher proportions of spermatozoa from African drones may have been used by queens of both European and African matrilines. Our results differ from those of previous studies with EHB queens inseminated with European drones. In those studies the patriline composition of worker brood occurred at expected ratios and did not demonstrate a bias for any particular patriline (Laidlaw and Page, 1984; Moritz, 1986; Sasaki et al., 1995). However, Franck et al. (1999) recently suggested non-random sperm use by an inseminated queen, but only during the first few months of egg laying. Biased sperm use by multiply mated queens has also been suggested recently for the ant, Proforma longiseta (Fernandez-Escudero et al., 2002).

There are at least five possible explanations for our results, each with a different likelihood of contributing significantly to the outcome of the study. First, our use of $c d$ color marker potentially could have contributed to lower numbers of European paternity workers. Several authors have suggested slightly reduced viability for $c d$ drones (Tucker, 1986; Berg et al., 1997), and Page and Erickson (1986) observed a decline in brood with $c d$ patrilines over time. Thus, our results may not have reflected an advantage associated with African paternity, but possible disadvantages associated with lower fertilization success from $c d$ sperm or reduced developmental success for $c d$ brood. However, subviability associated with the $c d$ trait cannot explain the equal proportions of African and European paternity workers during the first month of our study, or the increasing proportions of
European paternity workers during the final two months of sampling. One queen with European maternity produced a majority of workers with European paternity. Indeed, there is no association between the $c d$ trait and any aspect of viability in workers or queens (Taber and Wendell, 1958; Tucker, 1986; Schneider and DeGrandi-Hoffman, $2002,2003)$. The $c d$ trait is a natural color variant that occurs over large geographic areas and expression is not associated with inbreeding (Page et al., 1991). Bee breeders regularly produce $c d$ queens for sale (Koehnen, 1999; Glenn and Glenn, 2001) and a recognized commercial value argues against compromised viability in $c d$ bees. Because our study colonies were out bred, it seems rather unlikely that reduced viability of $c d$ drones or workers can account for the overrepresentation of African paternity bees in our samples.

Second, our inseminated queens may have used African and European sperm equally, but workers may have preferentially reared larvae with African patrilines. Brood from different patrilines within a colony may vary in attractiveness to nurse bees, and this could influence the care they receive and the likelihood of developing to emergence (Robinson et al., 1994; Tilley and Oldroyd, 1997). However, preferential rearing of brood with African patrilines cannot account for the increasing proportions of European paternity workers collected during the latter part of our study, or the equal proportions of workers of each patriline collected at the beginning. Similarly, Schneider and DeGrandi-Hoffman (2002) found that workers do not exhibit preference for African or $c d$ paternity larvae when raising queens. It is therefore unlikely that the greater number of workers with African patrilines in our samples resulted solely from a rearing preference by workers.

Third, African sperm may have clumped in the queens' spermathecae resulting in greater production of brood with African patrilines during portions of the study. In previous studies the degree of sperm clumping in honeybees has been estimated to be less than $6 \%$, so clumping alone would not account for the high percentage of African patriline workers produced by queens of either matriline (Haberl and Tautz, 1998). Additionally, aggregations 
or clumps of sperm have not been found in histologically sectioned spermatheca of queens that had been instrumentally inseminated (Page et al., 1984). Franck et al. (1999) examined a queen inseminated with multiple drones and found evidence of sperm clumping at the beginning of the egg laying period, but more complete mixing of sperm over time. In contrast, our results suggested that the usage of African and European sperm was equal at the beginning of the egg laying period, but over time became biased toward African sperm. Our results taken in concert with those from previous studies suggest that sperm clumping alone cannot account for the greater production of workers with African paternity by our inseminated queens.

Fourth, while we inseminated each queen with equal volumes of African and European semen, a greater percentage of workers having African patrilines would be produced if African drones had higher numbers of spermatozoa than their European counterparts. However, African drones produce fewer spermatozoa than European drones (Rinderer et al., 1985). We inseminated our queens with equal volumes of African and European semen. Thus, if spermatozoa number alone had determined patriline composition in our colonies, then our study should have been biased toward workers of European paternity.

Fifth, a greater percentage of workers having African patrilines could result if the metabolic rate of sperm from African drones is greater than that of European drones and provides them an advantage in the process of egg fertilization. Each time an egg is laid by the queen, 10-100 spermatozoa are released (Bresslau, 1905; Adam, 1912). A higher metabolic rate for spermatozoa from African drones might enable them to penetrate eggs and fertilize them at higher rates compared to that of spermatozoa of European drones. We know that African bees have greater mass specific metabolic rates than European bees (Harrison and Hall, 1993) and this difference might be manifested in spermatozoa.

The percentage of workers having African patrilines produced by queens differed by as much as 20\% from month to month during our study. In contrast, Haberl and Tautz (1998) report that sperm usage by an open-mated queen remained constant in the short term and fluctuated only moderately over a period of a year. There are several possible reasons for this discrepancy. The open-mated queen contained sperm from at least seven drones as determined by the composition of the worker subfamilies. Our queens were instrumentally inseminated with sperm from two drones. While sperm use might not differ between naturally mated and instrumentally inseminated queens, the amount of spermatozoa remaining in the spermatheca after several months of egg laying might differ considerably based upon the number of drones that mated with the queen and the queen's rate of egg laying. The heterogeneity among queens in the patriline composition of their worker brood, particularly late in our study, might reflect variation due to the total number of eggs the queens had laid. Those laying more eggs might have greatly reduced the number of spermatozoa from the African drones in their spermatheca since they were used at higher rates earlier in the study. Previous studies involving sperm utilization used only European patrilines. Since the spermatozoa from the different European drones were used at similar rates, the variation caused by differences in egg laying among the queens would not have been evident. However, in our study the proportion of spermatozoa from African and European drones in the queens' spermatheca was changing throughout the study period, which may have caused variation due to differences in egg laying rates to become more apparent.

The results from this study provide at least a partial explanation of why the frequency of nuclear markers for European bees decreases over time in areas where African bees immigrate. If queens mated to both European and African drones produce more workers having African paternity than expected from the ratio of matings with African drones, larvae with African paternity that could be reared into queens would also be in greater than expected ratios. The combination of having greater proportions of worker larvae with African patrilines available to be reared into queens and queens with African paternity having behavioral and development time advantages over their European counterparts (DeGrandi-Hoffman et al., 1998; Schneider et al., 2001; Schneider and DeGrandiHoffman, 2002) would greatly increase the 
probability of having the new queen in a colony be one with an African genotype.

When AHB immigrate into an area with a resident EHB population, most queen matings should be with European drones, at least during the initial stages of the AHB invasion. Whether greater percentages of workers with African paternity workers are reared in colonies where queens have mated with a majority of European drones remains to be determined. In this study we used a single genetic line of European honeybees. Queens and drones from other European lines need to be tested to determine if our findings apply to European matrilines in general. If a majority of African patrilines occur in colonies headed by queens with European maternity, it would further accelerate the loss of European patrilines in the population and the Africanization process.

\section{ACKNOWLEDGEMENTS}

We express our gratitude to M. Chambers, T. Deeby, J. Gregory, J.H. Martin, R. McGuire, J. Nussman, V. Torrejon and R. Wright for collecting samples, maintaining colonies, and identifying the patrilines. We also thank Diana Sammataro, Gordon Wardell and D.C. Gilley for their comments on the manuscript. The work was supported by USDA grant 2975980274 awarded to S.S.S. and G.D.-H.

Résumé - Composition des lignées paternelles des populations d'ouvrières dans des colonies d'abeilles domestiques (Apis mellifera) ayant à leur tête des reines inséminées avec du sperme de mâles africains ou européens. L'introduction et l'expansion des abeilles africanisées (AHB) dans l'hémisphère occidental a provoqué le déplacement de populations d'abeilles européennes (EHB) et la perte de marqueurs nucléaires européens. Les marqueurs nucléaires sont associés aux allèles des EHB hérités du père et indiquent la disparition de lignées paternelles des EHB dans les régions où les abeilles africanisées ont immigré. Les raisons de cette perte de lignées paternelles des EHB tournent généralement autour des avantages physiologiques et comportementaux que les reines de paternité africaine ont sur celles de paternité européenne lors du remplacement de la reine. Néanmoins des reines de descendance africaine pourraient avoir aussi un avantage numérique si le taux d'utilisation du sperme des mâles africains pour fertiliser les oeufs est supérieur à celui des mâles européens. Des reines d'abeilles ayant des lignées maternelles soit africaines soit européennes ont été inséminées avec des mâles africains ou européens pour créer des colonies ayant des lignées paternelles africaines et européennes. Pour connaitre le taux de sperme des deux types de mâles utilisé, on a déterminé chaque mois la proportion d'ouvrières de chaque lignée paternelle en encageant du couvain operculé. Environ $50 \%$ du couvain d'ouvrières de chaque lignée maternelle étaient engendrés par les mâles africains au cours du premier mois et des deux derniers mois de l'étude (F1). Pourtant, durant les trois autres mois de l'étude, les deux lignées maternelles ont produit des pourcentages significativement plus grands de couvain de paternité africaine que les $50 \%$ attendus (Tab. I). $61 \%$ des ouvrières issues des reines de lignée maternelle européenne et $65 \%$ de celles issues de reines de lignée maternelle africaine avaient une paternité africaine. Il y avait un degré élevé d'hétérogénéité parmi les reines des deux lignées maternelles en ce qui concerne les pourcentages d'ouvrières de paternité africaine qu'elles avaient produites (Tab. II). Certaines reines ont produit moins de $50 \%$ d'ouvrières de paternité africaine au cours du premier mois suivant l'insémination, puis en ont produit plus de $50 \%$ durant le reste de l'étude. D'autres ont produit en majorité des ouvrières de paternité africaine à toutes les périodes d'échantillonnage. Puisque le sperme des mâles africains est utilisé à un taux plus élevé que celui des mâles européens, les ouvrières de paternité africaine constituent la majeure partie de la population de la colonie et sont peut-être aussi les candidates qui peuvent donner les nouvelles reines. Les avantages comportementaux et physiologiques qu'ont les reines de paternité africaine sur les reines de paternité européenne, associés à un avantage numérique, fournissent une explication au moins partielle au fait que la fréquence des marqueurs nucléaires pour les abeilles européennes diminue avec le temps dans les régions où les abeilles africaines immigrent.

Apis mellifera / Apis mellifera scutellata / utilisation du sperme / processus d'africanisation

Zusammenfassung - Zusammensetzung von Patrilinien in Arbeiterinnenpopulationen von Völkern der Honigbienen (Apis mellifera L.), deren Königinnen mit Sperma von afrikanischen und europäischen Drohnen besamt wurden. Die Einführung und Verbreitung der afrikanisierten Honigbienen (Apis mellifera) (AHB) in die westliche Hemisphere hat zu einer Verdrängung der Populationen der europäischen Honigbienen (EHB) und zum Verlust von bestimmtem europäischen DNA Sequenzen im Zellkern geführt. Diese Kernsequenzen sind assoziiert mit ererbten EHB Allelen und weisen auf den Schwund von EHB Patrilinien in Gebieten hin, 
in die AHB eingedrungen sind. Die Gründe für den Verlust der EHB Patrilinien beruhen vor allem auf Vorteilen in der Physiologie und im Verhalten der Königinnen der afrikanischen Patrilinien gegenüber denen der europäischen Patrilinien bei der Umweiselung. Königinnen afrikanischer Abstammung könnten jedoch auch zahlreiche Vorteile haben, wenn die Spermatozoen von afrikanisierten Drohnen häufiger zur Eibefruchtung genutzt werden als die der europäischen Drohnen.

Zur Bestimmung, ob Spermatozoen der afrikanischen und europäischen Drohnen im gleichen Verhältnis benutzt werden, wurden Königinnen afrikanischer bzw. europäischer Abstammung mit gleichen Mengen Sperma von afrikanischen und europäischen Drohnen besamt. Das führte $\mathrm{zu}$ Völkern mit afrikanischen und europäischen Patrilinien. Zur Bestimmung der Rate der Nutzung von beiden Spermatozoentypen wurde das Verhältnis der Patrilinien der Völker einmal pro Monat bestimmt. Dazu wurden verdeckelte Brutwaben in Käfigen isoliert. Bei beiden Königinnen Typen stammten etwa $50 \%$ der Arbeiterinnenbrut im ersten und in den beiden letzten Monaten der Untersuchung von den afrikanischen Drohnen (Abb. 1). In den anderen drei Monaten stammten jedoch $>70 \%$ der Arbeiterinnen von afrikanischen Drohnen. Legt man die Gesamtdauer des Versuchs zugrunde, so ergaben sich höhere Prozentsätze von afrikanischem gegenüber europäischem Erbgut als die erwarteten $50 \%$. Das galt für beide Königinnenlinien (Tab. I). Die Königinnen der europäischen Matrilinie erzeugten $61 \%$ Arbeiterinnen mit afrikanischen Vätern, die der afrikanischen Matrilinien $65 \%$. Es gab eine große Heterogenität der Königinnen bei beiden Abstammungen in Bezug auf die Prozentzahl ihrer afrikanischen Nachkommen (Tab. II). Einige Völker hatten < $50 \%$ Arbeiterinnen von afrikanischen Vätern in den ersten Monaten nach der Besamung und danach $>50 \%$. Andere hatten bei allen Probennahmen vor allem Arbeiterinnen von afrikanischen Vätern. Da die Spermatozoen der afrikanischen Drohnen in größerer Zahl als die der europäischen genutzt werden, stellen die afrikanischen Patrilinien die Mehrzahl der Volkspopulation und vielleicht auch die Mehrzahl der Brut zur Königinnenaufzucht. Die physiologischen und verhaltensbedingten Vorteile der Königinnen der afrikanischen Patrilinien gegenüber denen der europäischen, verbunden mit einer Überzahl bei der Aufzucht von Königinnen, erklärt zumindest zu einem Teil, warum die Frequenz der für europäische Bienen typischen nuklearen Sequenzen mit der Zeit in Gebieten abgenommen haben, in die afrikanisierte Bienen eingedrungen sind.

Apis mellifera / Apis mellifera scutellata / Spermanutzung / Prozess der Afrikanisierung

\section{REFERENCES}

Adam A. (1912) Bau und Mechanismus des Receptaculum seminis bei den Bienen, Wespen und Ameisen, Zool. Jb. Abt. Anat. Ontog. Tiere. $35,1-74$.

Berg S., Koeniger N., Fuchs S. (1997) Body size and reproductive success of drones (Apis mellifera L.), Apidologie 28, 449-460.

Bresslau Ev. (1905) Der Samenblasengang der Bienenkonigin, Zool. Anz. 29, 299-323.

DeGrandi-Hoffman G., Watkins J.C., Collins A.M., Loper G.M., Martin J.H., Arias M.C., Sheppard W.S. (1998) Queen developmental time as a factor in the Africanization of European honey bee (Hymenoptera: Apidae) populations, Ann. Entomol. Soc. Am. 91, 52-58.

Fernández-Escudero I., Pamilo P., Seppä P. (2002) Biased sperm use by polyandrous queens of the ant Proformica longiseta, Behav. Ecol. Sociobiol. 51, 207-213.

Franck P., Coussy H., Le C.Y., Solignac M., Garnery L., Cornuet J.M. (1999) Microsatellite analysis of sperm admixture in honeybee, Insect Mol. Biol. 8, 419-421.

Glenn T., Glenn S. (2001) Cordovan: Bees of a different color, http://members.aol.com/queenb95/ cordovan.html (verified on 3 March 2003).

Haberl M., Tautz D. (1998) Sperm usage in honeybees, Behav. Ecol. Sociobiol. 42, 247-255.

Hall H.G. (1990) Parental analysis of introgressive hybridization between African and European honeybees using nuclear DNA RFLPs, Genetics 125, 611-621.

Harbo J.R. (1990) Artificial mixing of spermatozoa from honeybees and evidence for sperm competition, J. Apic. Res. 29,151-158.

Harrison J.F., Hall H.G. (1993) African-European honeybee hybrids have low non-intermediate metabolic capacities, Nature 363, 258-259.

Koehnen C.F. and Sons, Inc. (1999) Our bee process, http://www.koehnen.com/process.htm (verified on 3 March 2003).

Koeniger N., Koeniger G. (2000) Reproductive isolation among species of the genus Apis, Apidologie 31, 313-339.

Laidlaw H.H. Jr. (1977) Instrumental insemination of honeybee queens, Dadant \& Sons, Hamilton, IL, USA.

Laidlaw H.H., Page R.E. (1984) Polyandry in honey bees (Apis mellifera L.): Sperm utilization and intracolony genetic relationships, Genetics 108, 985-997.

Lobo J.A., DelLama M.A., Mestriner M.A. (1989) Population differentiation and racial admixture in the Africanized honeybees (Apis melifera L.), Evolution 43, 794-802.

Moritz R.F.A. (1986) Intracolonial worker relationship and sperm competition in the honeybee, Experientia 42, 445-448. 
Nielsen D.I., Ebert P.R., Page R.E. Jr., Hunt G.J., Guzman-Novoa E. (2000) Improved polymerase chain reaction - based mitochondrial genotype assay for identification of Africanized honey bee (Hymenoptera: Apidae), Ann. Entomol. Soc. Am. 93, 1-6.

Otis G.W. (1980) The swarming biology and population dynamics of the Africanized honey bee, Ph.D. dissertation, University of Kansas.

Page R.E. Jr., Erickson E.H. (1986) Kin recognition during emergency queen rearing by worker honeybees (Hymenoptera: Apidae), Ann. Entomol. Soc. Am. 79, 460-467.

Page R.E., Kimsey R.B., Laidlaw H.H. (1984) Migration and dispersal of spermatozoa in the spermathecae of queen honeybees (Apis mellifera L.), Experientia 40, 182-184.

Page R.E. Jr., Metcalf R.A., Metcalf R.L., Erickson E.H. Jr., Lampman R.L. (1991) Extractable hydrocarbons and kin recognition in honeybees (Apis mellifera L.), J. Chem. Ecol. 17, 745-756.

Parker G.A. (1984) Sperm competition and the evolution of mating strategies, in: Smith R.L. (Ed.), Sperm competition and the evolution of animal mating systems, Academic Press, London, pp. 1-60.

Rinderer T.E. (1986) Africanized bees: The Africanization process and potential range in the United States, Bull. Entomol. Soc. Am. 31, 222227.

Rinderer T.E., Hellmich R.L., Danka R.G., Collins A.M. (1985) A comparison of Africanized and European drones: Weights, mucus gland and seminal vesicle weights, and counts of spermatozoa, Apidologie 16, 407-412.

Rinderer T.E., Stelzer J.A., Oldroyd B.P., Buco S.M., Rubink W.L. (1991) Hybridization between European and Africanized honeybees in the neotropical Yucatan peninsula, Science 253, 309-311.

Robinson G.E., Page R.E. Jr., Arensen N. (1994) Genotypic differences in brood rearing in honeybee colonies: context-specific?, Behav. Ecol. Sociobiol. 34, 125-137.
Sasaki K., Satoh T., Obara Y. (1995) Sperm utilization by honeybee queens; DNA fingerprinting analysis, Appl. Entomol. Zool. 30, 335-341.

Schneider S., DeGrandi-Hoffman G. (2002) The influence of worker behavior and paternity on the development and emergence of honeybee queens, Insectes Soc. 49, 306-314.

Schneider S., DeGrandi-Hoffman G. (2003) The influence of paternity on virgin queen success in hybrid colonies of European and African honeybees, Anim. Behav. (in press).

Schneider S., Painter-Kurt S., DeGrandi-Hoffman G. (2001) The role of the vibration signal during queen competition in colonies of the honeybee (Apis mellifera L.), Anim. Behav. 61, 1173-1180.

Sheppard W.S., Rinderer T.E., Mazzoli J., Stelzer J.A., Shimanuki H. (1991) Gene flow between African-and European-derived honeybee populations in Argentina, Nature 349, 782-784.

Sokal R.R., Rohlf F.J. (1995) Biometry, Freeman, New York.

Suazo A., McTiernan R., Hall H.G. (1998) Differences between African and European honeybees (Apis mellifera L.) in random amplified polymorphic DNA (RAPD), J. Hered. 89, 32-36.

Taber S. III, Wendel J. (1958) Concerning the number of times queen bees mate, J. Econ. Entomol. 51, 786-789.

Taylor O.R. (1977) The past and possible future spread of Africanized honeybees in the Americas, Bee World 58,19-30.

Tilley C.A., Oldroyd B.P. (1997) Unequal subfamily proportions among honeybee queen and worker brood, Anim. Behav. 54,1483-1490.

Tucker K.W. (1986) Visible mutants, in: Rinderer T.E. (Ed.), Bee Genetics and Breeding, Academic Press, Orlando, FL, USA, pp. 57-90.

Walsh P.S., Metzger D.A., Higuchi R. (1991) Chelex ${ }^{\circledR} 100$ as a medium for simple extraction of DNA for PCR-based typing from forensic material, Biotechniques 10, 506-513. 